\title{
Effect of Stress Induced by Anesthesia and Surgery on Peripheral Blood Mobilization of Stem Cells in Horses
}

Jishnu Rao Gutti ${ }^{\star}$, B Justin William, Ravi Sundar George, TA Kannan, G Dhanan Jaya Rao and V Leela

Department of Veterinary Surgery and Radiology, Madras Veterinary College, Tamil Nadu Veterinary and Animal Sciences University, Chennai, India

\begin{abstract}
Objective: The study was conducted to evaluate the effect of stress induced by general anesthesia and surgery on the peripheral mobilization of stem cells in horses.
\end{abstract}

Methods: The study was conducted in 12 horses that reported for elective surgical procedures warranting general anesthesia and were randomly divided into group I and group II each consisting of 6 horses. The study included evaluation of plasma cortisol level, stress leukogram and mobilization of peripheral blood Hematopoietic Stem Cells (HSCs), Mesenchymal Stem Cells (MSCs)/progenitor cells. Group I horses were pre-medicated with a butorphanoldexmedetomidine-acepromazine combination and further induced and maintained with ketamine-midazolam. Group II horses were pre-medicated with butorphanol-xylazine and induced and maintained with ketamine alone.

Results: The change in the pattern of the differential count in terms of stress leukogram was marked when the horses were induced and maintained with ketamine. The mean percentage of CD34 positive cells in pre-anesthesia, during anesthesia and post-anesthesia were $0.13 \pm 0.00,0.31 \pm 0.02$ and $0.64 \pm 0.03$ in group I and in group II, $0.12 \pm 0.00,0.30 \pm 0.01$ and $0.70 \pm 0.03$ respectively. Similarly, the mean percentage of CD105 positive cells in preanesthesia, during anesthesia and post-anesthesia were $0.01 \pm 0.00,0.01 \pm 0.00$ and $0.02 \pm 0.00$ in group I and in group II, $0.01 \pm 0.00,0.01 \pm 0.00$ and $0.03 \pm 0.00$ respectively. The Perusal of mean revealed a significant increase in CD34 positive cells in both the groups on the $6^{\text {th }}$ postoperative day and revealed no significant increase in CD105 positive cells in both the groups.

Conclusion: Though the stress indicators in terms of plasma cortisol level and stress leukogram were high after sedation and during anesthesia; mobilization of HSCs was appreciated only after $6^{\text {th }}$ postoperative day indicating mobilization was occurring during the reparative and healing period.

Keywords: Equine anesthesia; CD34; CD105; Progenitor; Hematopoietic stem cells

Abbreviations: HSCs: Hematopoietic Stem Cells; EPCs: Endothelial Progenitor Cells; MSCs: Mesenchymal Stem Cells; SCF: Stem Cell Factor; PBS: Phosphate Buffer Solution

\section{Introduction}

Stem cell mobilization is a process by which the HSCs, Endothelial Progenitor Cells (EPCs) and MSCs from the bone marrow are mobilized to the periphery and available for further therapeutic procedures [1]. The functions and regulation of HSCs within the niche is based on a highly complex process involving not only intrinsic cues within the HSC themselves but signaling from the surrounding microenvironment in which they reside. Disruption of one or more of these niche interactions can result in the release of HSCs from the niche and their trafficking from the bone marrow to the peripheral circulation, a process termed peripheral blood stem cell mobilization. Mobilization can be achieved through administration of chemotherapy hematopoietic growth factors, chemokines, and small-molecule chemokine receptor inhibitors or antibodies against HSC niche interactions [2]. Anesthesia and surgery increase endogenous catecholamine as a response to the activity of sympathetic nervous system due to nocifensive response to surgery and a wider stress response to anesthetic-induced stress and hypoxia [3]. Stress-induced signals activate neutrophils and osteoclasts which in turn cause shedding and release of membrane-bound Stem Cell Factor (SCF), the proliferation of HSC and play a major role in stem cell mobilization [4]. The host immune system response to inflammation increases the release of leukocytes that include HSC from the bone marrow [5]. MSCs and HSCs are used for stem cell therapy/ regenerative therapy in equines for the management of tendon injury, osteoarthritis, wound healing and other degenerative disorders [6]. No studies were available on the extent of mobilization of HSCs and MSCs following anesthesia in horses to predict the volume of peripheral blood to be collected for the collection of a required number of stem cells by ficoll gradient density method or apheresis for therapy. The study included evaluation of the plasma cortisol level, stress leukogram and mobilization of peripheral blood HSCs/progenitor cells as a response to stress during total intravenous anesthesia using the midazolamketamine mixture in butorphanol-dexmedetomidine-acepromazine pre-medicated horses and compare with ketamine in butorphanolxylazine pre-medicated horses for surgery.

\section{Methods}

The clinical study was conducted on horses of either sex referred for elective surgical procedures warranting general anesthesia as approved by the Dean of Clinics and The Dean, Faculty of Veterinary Sciences, Tamil Nadu Veterinary and Animal Sciences University, India. On

*Corresponding author: Jishnu Rao Gutti, Department of Veterinary Surgery and Radiology, Madras Veterinary College, Tamil Nadu Veterinary and Animal Sciences University, Chennai, India, Tel: 706-308-0578; E-mail: jishnu.rao@gmail.com; jishnu. rao@uga.edu

Received October 11, 2018; Accepted October 31, 2018; Published November 08, 2018

Citation: Gutti JR, William BJ, George RS, Kannan TA, Rao GDJ, et al. (2018) Effect of Stress Induced by Anesthesia and Surgery on Peripheral Blood Mobilization of Stem Cells in Horses. Stem Cell Res Ther 8: 440. doi: 10.4172/2157-7633.1000440

Copyright: ( 2018 Gutti JR, et al. This is an open-access article distributed under the terms of the Creative Commons Attribution License, which permits unrestricted use, distribution, and reproduction in any medium, provided the original author and source are credited. 
admission, the horses were subjected to pre-operative check-up that included physiological observations, complete hematology, and serum biochemical analysis. The American Society of Anesthesiologists (ASA) classification [7] was followed to categorize the health status of the horses. The 12 horses selected on basis of ASA 1 status were randomly allotted to group I and group II each consisting of 6 horses. The feed was withheld for 12 hours but not water prior to anesthesia [8]. All the trials were conducted in the forenoon to avoid diurnal variations. All the horses in group I and II were pre-medicated with butorphanol $(0.01 \mathrm{mg} / \mathrm{kg} \mathrm{BW})$ intravenously. After 20 minutes, group I horses were administered with dexmedetomidine $(5.00 \mu \mathrm{g} / \mathrm{kg} \mathrm{BW})$ intravenously followed by acepromazine $(0.03 \mathrm{mg} / \mathrm{kg} \mathrm{BW})$ intravenously 15 minutes later. Group II horses were administered with xylazine $(1.10 \mathrm{mg} / \mathrm{kg}$ BW) intravenously 20 minutes after the administration of butorphanol. At peak sedation, the horses were induced with a mixture of ketamine hydrochloride and midazolam, administered intravenously at the dose rate of 2.00 and $0.05 \mathrm{mg} / \mathrm{kg}$ body weight respectively in group I horses and ketamine alone at a dose rate of $2.20 \mathrm{mg} / \mathrm{kg}$ in group II horses. Further maintenance was carried out with the same combinations in the respective groups of horses.

Plasma cortisol level was assessed pre-operatively, intraoperatively, post-operatively and after 24 hours of surgery, $2^{\text {nd }}, 4^{\text {th }}$ and $6^{\text {th }}$ postoperative days. The plasma cortisol estimation was analyzed based on direct immune enzymatic method and values were estimated in $\mathrm{ng} / \mathrm{dl}$ [9-11]. Stress leukogram was assessed pre-operatively, intraoperatively, post-operatively and after 24 hours of surgery, $2^{\text {nd }}, 4^{\text {th }}$ and $6^{\text {th }}$ postoperative days. The mean total leukocyte count (thousand $/ \mathrm{mm}^{3}$ ) and differential count (\%) were estimated by auto-hemolyser [12].

\section{Equine peripheral HSC/progenitor cell mobilization/MSC}

Peripheral HSCs/progenitor cells and MSCs mobility parameters were assessed pre-operatively, intra-operatively and postoperatively after 6 days of surgery. $5 \mathrm{ml}$ of blood was collected in EthyleneDiamine-Tetra-Acetic-acid (EDTA) vial from the cannulated jugular vein of horses. The collected blood was diluted with equal parts (1:1) of Phosphate Buffer Solution (PBS) and gently mixed [13]. To $4 \mathrm{ml}$ of ficoll medium, the diluted blood was gently overlaid and centrifuged at $1600 \mathrm{rpm}$ for 20 minutes. From the layered blood, buffy coat was gently isolated with a sterile pipette and transferred to a sterile Falcon tube which was then centrifuged at $1200 \mathrm{rpm}$ for 10 minutes. The supernatant was discarded and the pellet was dissolved in $5 \mathrm{ml}$ of PBS and was centrifuged at $1200 \mathrm{rpm}$ for 15 minutes. This process was repeated till all the red blood cells were washed off to obtain a clear white pellet. $20 \mu \mathrm{L}$ of the cell suspension was mixed with $20 \mu \mathrm{L}$ of trypan blue stain and cells were enumerated (minimum concentration of 1 to $5 \times 10^{6}$ cells $/ \mathrm{ml}$ ) and checked for viability [14]. The cells were frozen at a concentration of $2 \times 10^{6}$ cells by re-suspending in a cryo-preservation medium (90\% FBS and 10\% dimethyl sulfoxide) decreasing at the rate of $-1^{\circ} \mathrm{C}$ until $-80^{\circ} \mathrm{C}$; at this temperature, cells were held for 1 week and then transferred to a liquid nitrogen tank for long-term storage. For thawing, the cryovials with ePB-HSC were placed in a $37^{\circ} \mathrm{C}$ water bath for 1 to 2 minutes and then centrifuged at $1600 \mathrm{~g}$ for 10 minutes and washed with non-inductive medium to eliminate dimethyl sulfoxide, $20 \mu \mathrm{l}$ of the cell suspension was mixed with $20 \mu \mathrm{l}$ of trypan blue stain and cells were enumerated using a hemocytometer (minimum concentration of 1 to $5 \times 10^{6} \mathrm{cell} / \mathrm{s} / \mathrm{ml}$ ) and checked for viability [15-17].

\section{Flow cytometry protocol}

The flow cytometry (Bio-rad, USA) protocol required the adjustment of cell concentration in cell suspension to 1 to $5 \times 10^{6}$ cells/ $\mathrm{ml}$ to which $2 \mathrm{ml}$ of $0.5 \%$ PBS with Bovine Serum Albumin (blocking buffer) was added and was gently shaken and centrifuged at 1500 to $2000 \mathrm{rpm}$ for 5 minutes. The supernatant was discarded and the cells were fixed with $1.00 \mathrm{ml}$ of 2 to $4 \%$ paraformaldehyde (fixing buffer) and incubated at room temperature for 10 minutes. Centrifuged at 1500 to $2000 \mathrm{rpm}$ for 5 minutes and washed cells once with $1.00 \mathrm{ml}$ blocking buffer and centrifuged. The supernatant was discarded and $1 \mathrm{ml}$ of pre-cooled $90 \%$ methanol (penetrating buffer) was added and incubated at the room temperature for 10 minutes. Centrifuged at 1500 to $2000 \mathrm{rpm}$ for 5 minutes and washed with $2 \mathrm{ml}$ of blocking buffer and centrifuged. The cells were incubated in blocking buffer for 30 minutes at room temperature and primary antibody at $0.025 \mathrm{mg} / \mathrm{ml}$ was added and incubated for 90 minutes at room temperature (CD34 positive for HSC and CD105 positive for MSC). Centrifuged at 1500 to 2000 rpm for 5 minutes and washed once with $2 \mathrm{ml}$ of blocking buffer and centrifuged again under the same condition. The cells were incubated with FITC-conjugated secondary antibodies for 40 minutes at room temperature and centrifuged at 1500 to $2000 \mathrm{rpm}$ for 5 minutes, then washed once with $2 \mathrm{ml}$ of blocking buffer and centrifuged at the same condition. To the re-suspended cells, $1.00 \mathrm{ml}$ of PBS was added and analyzed on the flow cytometer $[15,16,18]$. The data obtained were statistically analyzed using completely randomized block design and one way ANOVA was used to compare the means of the parametric values. Differences between the data were considered significant when $\mathrm{P}<0.05$. The statistical analysis was done using SPSS 17 software.

\section{Results and Discussion}

Plasma cortisol level was assessed pre-operatively, intra-operatively, post-operatively and after 12 hours of surgery and the statistical analysis revealed no significant difference between both the groups of horses (Table 1) but uniformly, highly significant increase could be observed following sedation and declined to normal on $6^{\text {th }}$ postoperative day. The stress response to surgery and anesthesia was characterized by increased secretion of the pituitary hormones and the activation of the sympathetic nervous system. The changes in the pituitary hormones secretion had a secondary effect on hormone secreted from target organs-released corticotropin from the pituitary stimulated cortisol secretion from adrenal cortex [19]. The present study showed a significant increase in the plasma cortisol value during the post-operative period in horses that were pre-medicated with xylazine-butorphanol, induced and maintained with ketamine alone when compared with horses that were pre-medicated with dexmedetomidine-acepromazine-butorphanol, induced and maintained with ketamine-midazolam which concurred with the findings of Prunier, et al. [20], Carroll, et al. [21], Prunier, et al. [22] and Moya, et al. [23] who opined that it was due to the activation of the hypothalamic-pituitary-adrenal axis and also due to xylazine and ketamine anesthesia which was attributed to decreased breakdown of plasma cortisol caused by reduction in hepatic blood flow during surgery and therefore elevated the plasma half-life of cortisol [11,2428]. The gradual decrease in plasma cortisol level in the post-operative period and return near to base value after a week could be attributed the use of analgesics. The findings of the current study concurred with Davis, et al. [3], Nogueira, et al. [26], Roth, et al. [29], Robertson, et al. [30] and Montane, et al. [31].

Total leukocyte count (thousands $/ \mathrm{mm}^{3}$ ) values pre-operatively, after sedation, after recovery, after 24 hours, $2^{\text {nd }}, 4^{\text {th }}$ and $6^{\text {th }}$ day were recorded in group I and II and were analyzed (Table 1). Statistical analysis revealed no significant difference between both the groups 
Citation: Gutti JR, William BJ, George RS, Kannan TA, Rao GDJ, et al. (2018) Effect of Stress Induced by Anesthesia and Surgery on Peripheral Blood Mobilization of Stem Cells in Horses. Stem Cell Res Ther 8: 440. doi: 10.4172/2157-7633.1000440

Page 3 of 5

of horses. Total lymphocyte count (\%) values pre-operatively, after sedation, after recovery, after 24 hours were recorded in group I and II and were analyzed (Table 1). Statistical analysis revealed a significant decrease $(\mathrm{P}<0.05)$ in the lymphocytic values during the post-operative period in both the groups of horses. The values increased but returned to base values after recovery and no significant variation was evident between the groups. Total neutrophil count (\%) values pre-operatively, after sedation, after recovery, after 24 hours, $2^{\text {nd }}, 4^{\text {th }}$ and $6^{\text {th }}$ day were recorded in group I and II and were analyzed (Table 1). Statistical analysis revealed a significant increase $(\mathrm{P}<0.05)$ in the neutrophil values in post-operative period in horses that were pre-medicated with xylazine-butorphanol, induced and maintained with ketamine when compared with horses that were pre-medicated with dexmedetomidineacepromazine-butorphanol, induced and maintained with ketaminemidazolam. Total eosinophil count (\%) values pre-operatively, after sedation, after recovery, after 24 hours, $2^{\text {nd }}, 4^{\text {th }}$ and $6^{\text {th }}$ day were recorded in group I and II and were analyzed (Table 1). Statistical analysis revealed no significant difference between both the groups of horses. Total monocyte count (\%) values pre-operatively, after sedation, after recovery, after 24 hours, $2^{\text {nd }}, 4^{\text {th }}$ and $6^{\text {th }}$ day were recorded in group I and II and were analyzed (Table 1). Statistical analysis revealed a significant increase $(\mathrm{P}<0.05)$ in the monocyte count during the post-operative period in horses that were pre-medicated with xylazine-butorphanol, induced and maintained with ketamine when compared with horses that were pre-medicated with dexmedetomidine-acepromazinebutorphanol, induced and maintained with ketamine-midazolam. The present study revealed neutrophilia after pre-medication in both the groups followed by lymphocytopenia, eosinopenia and monocytosis as stimulating the "classical stress response". However, the values returned to the base value after 2 to 4 days in the post-operative period. The change in the pattern of the differential count in terms of stress leukogram was marked when the horses were induced and maintained with ketamine alone. The findings of the present study concurred with Sankar, et al. [32], Malik, et al. [33] and Malik, et al. [34]. Stress-induced alteration in endocrine function could lead to a delay in wound healing, immune suppression and stress leukogram [35]. Membrane-bound SCF shed and release due to activation of neutrophils and osteoclasts in stress apart from HSC proliferation; VLA-4 and P/E selectins adhesive molecules either get activated or degraded [36].

The calculated mean mononuclear cells harvested from $1 \mathrm{ml}$ of peripheral blood ranged from $2.33 \pm 1.16$ to $2.96 \pm 0.95$ in both the groups: pre-anesthesia, during anesthesia and post-anesthesia and the cells were subjected to flow cytometry analysis. The mean percentage of CD34 and CD105 positive cells in pre-anesthesia, during anesthesia and post-anesthesia, were recorded in group I and II and were analyzed (Table 2). Perusal of mean revealed a significant increase in CD34 positive cells in both the groups on $6^{\text {th }}$ postoperative day and revealed no significant increase in CD105 positive cells in both the groups (Figure 1). Equine peripheral blood stem cells were a good source of stem cells because of low invasivity, ease of harvest and low pain levels involving in harvesting procedure [14]. The stem cells harvested from peripheral blood could be used for stem cell-based therapy in equines.

The influence of anesthesia-induced stress and hypoxia on the mobilization of HSCs were not studied. Peripheral blood stem cells were harvested and the authors used CD34 as a positive marker for HSCs and CD105 as a positive marker for MSCs [36]. The mean

\begin{tabular}{|c|c|c|c|c|c|c|c|c|c|}
\hline Parameter & Group & Pre-operative & After sedation & After recovery & After 24 hours & $2^{\text {nd }}$ day & $4^{\text {th }}$ day & $6^{\text {th }}$ day & f-value \\
\hline \multirow{2}{*}{$\begin{array}{l}\text { TLC } \\
\text { (Thousands/ } \\
\text { cumm) }\end{array}$} & 1 & $7775.00 \pm 445.83$ & $8016.67 \pm 415.06$ & $8300.00 \pm 429.73$ & $8448.33 \pm 419.14$ & $8458.33 \pm 394.21$ & $8450.00 \pm 450.18$ & $8573.33 \pm 450.94$ & \multirow{2}{*}{$0.770^{\mathrm{NS}}$} \\
\hline & II & $7758.33 \pm 416.82$ & $6882.83 \pm 1284.33$ & $8283.33 \pm 411.84$ & $8450.00 \pm 394.76$ & $8516.67 \pm 384.42$ & $8208.33 \pm 250.47$ & $8278.33 \pm 234.67$ & \\
\hline \multirow{2}{*}{ L (\%) } & 1 & $26.50^{\mathrm{bc}} \pm 0.34$ & $25.50^{a} \pm 0.34$ & $26.50^{\mathrm{a}} \pm 3.42$ & $25.83^{\mathrm{ab}} \pm 0.70$ & $25.33^{a} \pm 0.33$ & $24.67^{a} \pm 0.33$ & $22.83^{a} \pm 0.48$ & \multirow{2}{*}{$1.493^{*}$} \\
\hline & II & $27.17^{c} \pm 0.80$ & $26.17^{b} \pm 0.60$ & $25.50^{\mathrm{a}} \pm 0.22$ & $25.17^{a} \pm 0.60$ & $24.67^{a} \pm 0.33$ & $24.33^{a} \pm 0.42$ & $22.50^{a} \pm 0.88$ & \\
\hline \multirow{2}{*}{ N (\%) } & I & $70.17^{a} \pm 0.17$ & $71.17^{b} \pm 0.17$ & $71.33^{b} \pm 0.33$ & $71.17^{b} \pm 0.54$ & $71.67^{b c} \pm 0.21$ & $72.33^{\text {de }} \pm 0.33$ & $73.00^{\text {ef }} \pm 0.00$ & \multirow{2}{*}{$4.766^{*}$} \\
\hline & II & $69.50^{\mathrm{a}} \pm 0.50$ & $70.67^{\mathrm{bc}} \pm 0.33$ & $71.50^{b} \pm 0.22$ & $71.50^{\mathrm{b}} \pm 0.43$ & $71.00^{b} \pm 0.73$ & $72.00^{\mathrm{cd}} \pm 0.58$ & $73.33^{f} \pm 0.99$ & \\
\hline \multirow{2}{*}{$E(\%)$} & 1 & $2.00^{\text {cd }} \pm 0.00$ & $2.00^{\text {cd }} \pm 0.00$ & $1.00^{\mathrm{a}} \pm 0.00$ & $1.50^{\mathrm{ab}} \pm 0.22$ & $1.83^{\mathrm{bc}} \pm 0.17$ & $1.67^{b} \pm 0.21$ & $1.33^{a} \pm 0.21$ & \multirow{2}{*}{$3.604^{\mathrm{NS}}$} \\
\hline & II & $1.50^{\mathrm{a}} \pm 0.22$ & $1.50^{\mathrm{a}} \pm 0.34$ & $1.00^{\mathrm{a}} \pm 0.00$ & $1.67^{b} \pm 0.42$ & $2.00^{\text {cd }} \pm 0.00$ & $2.00^{\text {cd }} \pm 0.00$ & $2.17^{d} \pm 0.17$ & \\
\hline \multirow{3}{*}{ M (\%) } & 1 & $1.33^{a} \pm 0.21$ & $1.33^{a} \pm 0.21$ & $1.17^{\mathrm{a}} \pm 0.17$ & $1.67^{\mathrm{ab}} \pm 0.21$ & $1.17^{a} \pm 0.17$ & $1.33^{\mathrm{a}} \pm 0.21$ & $1.00^{\mathrm{a}} \pm 0.00$ & \multirow{3}{*}{$4.177^{\mathrm{NS}}$} \\
\hline & II & $1.83^{b c} \pm 0.17$ & $1.67^{\mathrm{ab}} \pm 0.21$ & $2.00^{c} \pm 0.00$ & $1.67^{\mathrm{ab}} \pm 0.21$ & $2.67^{d} \pm 0.21$ & $1.67^{\mathrm{ab}} \pm 0.21$ & $2.00^{c} \pm 0.45$ & \\
\hline & II & $251.67 \pm 14.24$ & $272.50 \pm 16.67$ & $274.00 \pm 17.22$ & $262.50 \pm 16.52$ & $258.67 \pm 16.67$ & $259.17 \pm 16.67$ & $205.17 \pm 34.40$ & \\
\hline \multirow{2}{*}{$\begin{array}{l}\text { Plasma } \\
\text { Cortisol (Ng/dl) }\end{array}$} & I & $16.22 \pm 1.84$ & $124.00 \pm 5.48$ & $108.17 \pm 3.62$ & $89.33 \pm 3.01$ & $56.97 \pm 4.74$ & $39.87 \pm 3.29$ & $27.25 \pm 5.29$ & \multirow{2}{*}{$0.850^{\mathrm{NS}}$} \\
\hline & II & $18.15 \pm 1.12$ & $115.83 \pm 6.34$ & $130.67 \pm 6.15$ & $113.33 \pm 7.60$ & $85.30 \pm 8.89$ & $68.40 \pm 8.00$ & $36.06 \pm 2.33$ & \\
\hline
\end{tabular}

*Significant at $<0.05$; **Significant at $<0.01$; NS-Non-Significant

Table 1: Mean \pm S.E. Leukogram and serum bio-chemical parameters in group I and II.

\begin{tabular}{|c|c|c|c|c|c|c|c|}
\hline \multirow{2}{*}{ S. No. } & \multirow{2}{*}{ Details } & \multicolumn{3}{|c|}{ Group I } & \multicolumn{3}{|c|}{ Group II } \\
\hline & & PA & DA & PoA & PA & DA & PoA \\
\hline 1. & Volume of blood collected (ml) & $5.00 \pm 00$ & $5.00 \pm 00$ & $5.00 \pm 00$ & $5.00 \pm 00$ & $5.00 \pm 00$ & $5.00 \pm 00$ \\
\hline 2. & Total Leukocyte Count ( $\times 10^{3} /$ cumm) & $7.77 \pm 445.83$ & $8.26 \pm 357.52$ & $8.57 \pm 450.94$ & $7.75 \pm 416.82$ & $7.95 \pm 398.57$ & $8.27 \pm 234.67$ \\
\hline \multirow[t]{2}{*}{3.} & Calculated Mono nuclear cells in $1 \mathrm{ml}$ of blood $\times 10^{6}$ & $2.33 \pm 1.16$ & $2.47 \pm 1.21$ & $2.57 \pm 1.29$ & $2.96 \pm 0.95$ & $2.38 \pm 1.01$ & $2.48 \pm 1.25$ \\
\hline & \multicolumn{7}{|l|}{ Flow cytometer } \\
\hline 4. & No. of cells subjected to analysis $\times 10^{3}$ & $8.06 \pm 1.22$ & $10.19 \pm 0.56$ & $10.00 \pm 00$ & $8.50 \pm 0.56$ & $10.00 \pm 0.57$ & $10.16 \pm 0.40$ \\
\hline 5. & CD34+ \% & $0.13 \pm 00$ & $0.31 \pm 0.02$ & $0.64 \pm 0.03$ & $0.12 \pm 00$ & $0.30 \pm 0.01$ & $0.70 \pm 0.03$ \\
\hline 6. & CD105+ \% & $0.01 \pm 00$ & $0.01 \pm 00$ & $0.02 \pm 00$ & $0.01 \pm 00$ & $0.01 \pm 00$ & $0.03 \pm 00$ \\
\hline
\end{tabular}

PA-Pre-Anesthetic; DA-During Anesthesia; PoA-Post-Anesthesia

Table 2: Mean \pm S.E. of peripheral blood stem cells positive for CD34 and CD105 markers analysed by flow cytometer in group I and II. 
Citation: Gutti JR, William BJ, George RS, Kannan TA, Rao GDJ, et al. (2018) Effect of Stress Induced by Anesthesia and Surgery on Peripheral Blood Mobilization of Stem Cells in Horses. Stem Cell Res Ther 8: 440. doi: 10.4172/2157-7633.1000440

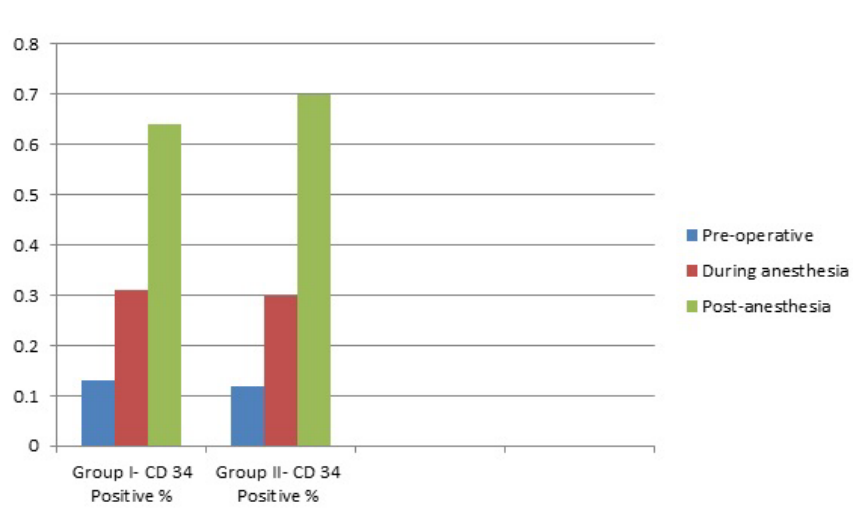

Figure 1: CD34 Positive cells percentage pre-operative, during anesthesia and post-anesthesia.

percentage of CD34 positive cells did not show any significant increase in both the groups during anesthesia from that of pre-anesthesia. However, the CD34 positive cells increased on the $6^{\text {th }}$ postoperative day. The mean percentage of CD105 positive cells did not show any significant increase throughout the study. The mean percentage of CD34 positive cells was highest on the $6^{\text {th }}$ postoperative day which could be due to the influence of the mobilization of HSCs and the reason could be attributed to the inactivation of the chemokine Stromal Cell-Derived Factor-1 (SDF-1) CXCL12, interleukin-8 (IL-8)/CXCL8 along with the proteolytic activity of elastase, cathepsin $\mathrm{G}$, proteinase 3, CD26 and metalloproteinase (MMP)-2 and 9 which disrupt the SDF1/CXCR 4 axis resulting in HSCs release [37]. The pattern of increase was comparable with post-exercise induced stem cell mobilization [13]. Though the insult of hypoxia and stress was reflected in terms of plasma cortisol and stress leukogram during anesthesia and surgery; mobilization of CD34 positive HSCs was noticed only during postoperative tissue reparative process or healing period irrespective of the anesthetic regimens.

\section{Conclusion}

The present study revealed that the magnitude of stress response was higher in terms of stress leukogram and plasma cortisol level in horses undergone induction and maintenance with ketamine alone when compared with ketamine and midazolam and uniformly the stress parameters elevated following sedation. The percentage of cells expressing CD34 marker increased only on the $6^{\text {th }}$ postoperative day in both the regimens and cells expressing CD105 did not show any variation revealing mobilization of HSCs occurred only during reparative and healing process; rather than as a response to stress. All the animals were subjected to anesthesia and surgery, hence could not be definitely be concluded that whether the mobility of HSCs was associated with post-anesthetic stress or post-surgical stress and it would be more appropriate to conclude that the mobilization of HSCs could be due to the reparative process towards the tissue insult caused by surgery.

\section{Acknowledgment}

The authors thank the Dean, Madras Veterinary College and Director of Clinics, Tamil Nadu Veterinary and Animal Sciences University for the facilities provided.

\section{References}

1. Pelus LM (2008) Peripheral blood stem cell mobilization: new regimens, new cells, where do we stand. Curr Opin Hematol 15: 285-292. [PubMed]
2. Hoggatt J, Pelus LM (2011) Mobilization of hematopoietic stem cells from the bone marrow niche to the blood compartment. Stem Cell Res Ther 2:13. [PubMed]

3. Davis CA (1990) The human stress response to surgical trauma and anesthesia. Equine Vet J 22: 304-305. [PubMed]

4. Cottler-Fox MH, Lapidot T, Petit I, Kollet O, Di Persio JF, et al. (2003) Stem cell mobilization. Hematology Am Soc Hematol Educ Program 419-437.

5. Zhao E, Xu H, Wang L, Kryczek I, Wu K, et al. (2012) Bone marrow and the control of immunity. Cell Mol Immunol 9: 11-19. [PubMed]

6. Markoski MM (2016) Advances in the use of stem cells in veterinary medicine: From basic research to clinical practice. Scientifica 2016: 4516920. [PubMed]

7. Kalchofner KS, Picek S, Ringer SK, Jackson M, Hässig M, et al. (2009) A study of cardiovascular function under controlled and spontaneous ventilation in isoflurane-medetomidine anaesthetized horses. Vet Anaesth Analg 36: 426435. [PubMed]

8. Duke-Novakovski T, Palacios $\square$ Jimenez C, Wetzel T, Rymes L, Sanchez $\square$ Teran AF (2015) Cardiopulmonary effects of dexmedetomidine and ketamine infusions with either propofol infusion or isoflurane for anesthesia in horses. Vet Anesth Analg 42: 39-49. [PubMed]

9. Johnston SD, Mather EC (1979) Feline plasma cortisol (hydrocortisone) measured by RIA. Am J Vet Res 40: 190-192. [PubMed]

10. Behera KK, Kapoor N, Seshadri MS, Rajaratnam S (2013) Acute adrenal insufficiency due to primary antiphospholipid antibody syndrome. Indian J Endocrinol Metab 17: 240-242. [PubMed]

11. Willemse T, Vroom MW, Mol JA, Rijnberk A (1993) Changes in plasma cortisol corticotropin, and alpha-melanocyte-stimulating hormone concentrations in cats before and after physical restraint and intradermal testing. Am J Vet Res 54: 69-72. [PubMed]

12. Sankar P, William BJ, Rao GDJ, Prathaban S, Kumar RS, et al. (2011) Cardiopulmonary and haematobiochemical alterations during ketamine or propofol anesthesia in acepromazine-xylazine premedicated horses. Indian J Vet Surg 32: 23-26.

13. Wiskemann $J(2013)$ Exercise in the setting of hematopoietic stem cell transplantation. Eur Rev Aging Phys Act 10: 15-18.

14. Huss R (2000) Isolation of primary and immortalized CD34-hematopoietic and mesenchymal stem cells from various sources. Stem cells 18: 1-9. [PubMed]

15. Martinello T, Bronzini I, Maccatrozzo L, lacopetti I, Sampaolesi M, et al. (2010) Cryopreservation does not affect the stem characteristics of multipotent cells isolated from equine peripheral blood. Tissue Eng Part C Methods 16: 771781. [PubMed]

16. Spaas JH, Broeckx S, Walle GR, Polettini M (2013) The effects of equine peripheral blood stem cells on cutaneous wound healing: a clinical evaluation in four horses. Clin Exp Dermatol 38: 280-284. [PubMed]

17. Zhang CC, Sadek HA (2014) Hypoxia and metabolic properties of hematopoietic stem cells. Antioxid Redox Signal 20: 1891-1901. [PubMed]

18. Lisio M, Parise G (2013) Exercise and hematopoietic stem and progenitor cells: protection, quantity, and function. Exerc Sport Sci Rev 41: 116-122. [PubMed]

19. Desborough JP (2000) The stress response to trauma and surgery. $\mathrm{Br} J$ Anaesth 85: 109-117. [PubMed]

20. Prunier A, Mounier AM, Hay M (2005) Effects of castration, tooth resection, or tail docking on plasma metabolites and stress hormones in young pigs. J Anim Sci 83: 216-222. [PubMed]

21. Carroll JA, Berg EL, Strauch TA, Roberts MP, Kattesh HG (2006) Hormonal profiles, behavioral responses and short-term growth performance after castration of pigs at three, six, nine, or twelve days of age. J Anim Sci 84 1271-1278. [PubMed]

22. Prunier A, Bonneau M, Von Borell EH, Cinotti S, Gunn M, et al. (2006) A review of the welfare consequences of surgical castration in piglets and the evaluation of non-surgical methods. Anim Welf 15: 277-289.

23. Moya SL, Boyle LA, Lynch PB, Arkins S (2008) Surgical castration of pigs affects the behavioural response to a low-dose Lipopolysaccharide (LPS) challenge after weaning. App Anim Behav Sci 112: 40-57. [PubMed]

24. Clarke RS, Johnston H, Sheriden B (1970) The influence of the anesthesia 
Citation: Gutti JR, William BJ, George RS, Kannan TA, Rao GDJ, et al. (2018) Effect of Stress Induced by Anesthesia and Surgery on Peripheral Blood Mobilization of Stem Cells in Horses. Stem Cell Res Ther 8: 440. doi: 10.4172/2157-7633.1000440

Page 5 of 5

and surgery on plasma cortisol, insulin and free fatty acids. $\mathrm{Br} \mathrm{J}$ Anaesth 42 : 295-299. [PubMed]

25. Udelsman R, Holbrook NJ (1994) Endocrine and molecular response to surgical stress. Curr Probl Surg 31: 658-720. [PubMed]

26. Nogueira GP, Silva JC (1997) Plasma cortisol levels in captive wild felines after chemical restraint. Braz J Med Biol Res 30: 1359-1361. [PubMed]

27. Ko JCH, Ronald EM, Doulgas N, Steven MF (2000) Cardiorespiratory response and plasma cortisol concentration in dogs treated with medetomidine before undergoing ovariohysterectomy. J Am Vet Med Assoc 217: 509-513.

28. Dembiec DP, Shrider RJ, Zonella A (2004) The effect of transport stress on tiger physiology and behaviour. Zoo Biol 23: 335-346.

29. Roth JA (1985) Cortisol as a mediator of stress associated immunosuppression in cattle. In: Animal Stress Am Physiol Soc, pp: 225-244.

30. Robertson SA, Steele CJ, Chen CL (1990) Metabolic and hormonal changes associated with athroscopic surgery in horses. Equine Vet $\mathrm{J}$ 22: 313-316. [PubMed]

31. Montane J, Marco I, Olvera JL, Perpinan D, Manteca X, et al. (2003) Effects of acepromazine on capture stress in Roe deer (Capreolus capreolus). J Wild Dis 39: 375-386. [PubMed]
32. Sankar P, William BJ, Rao GDJ, Prathaban S, Kumar RS, et al (2010) Oxidative stress response during surgery under ketamine/propofol anesthesia in acepromazine-xylazine premedicated horses. Indian J Anim Res 44: 113117.

33. Malik V, Kinjavdekar P, Aithal HP, Pawd AM (2011) Electrocardiographic and haematobiochemical changes during continuous intravenous infusion anesthesia with ketamine in medetomidine or midazolam premedicated buffaloes. Indian J Vet Surg 32: 9-13.

34. Malik V, Kinjavdeka P, Aithal HP, Pawd AM (2011) Continuous intravenous infusion anesthesia with propofol in medetomidine and midazolam premedicated buffaloes: a quantitative electrocardiographic and haematobiochemical study. Indian J Vet Surg 32: 14-18.

35. Wagner AE (1991) Stress associated with anesthesia and surgery. In: Mui WW, Hubbel JAE (eds.) Equine anesthesia, monitoring and emergency therapy. Mosby Year Book St. Louis, pp: 105-113.

36. Spaas JH, Gambacurta A, Polettini M, Broeckx S, Van Hoeck F, et al (2011) Purification and expansion of stem cells from equine peripheral blood, with clinical applications. Vlaams Diergeneesk Tijdschr 80: 129-135.

37. Lemoli RM, Addio DA (2008) Hematopoietic stem cell mobilization Haematologica 93: 321-324 